\title{
Stress-Induced Depression Is Alleviated by Aerobic Exercise Through Up-Regulation of 5-Hydroxytryptamine 1A Receptors in Rats
}

\author{
Tae Woon Kim ${ }^{1}$ Baek Vin Lim², Dongjin Baek³, Dong-Soo Ryu ${ }^{4}$, Jin Hee Seo ${ }^{5}$ \\ ${ }^{1}$ Department of Physiology, Kyung Hee University School of Medicine, Seoul, Korea \\ ${ }^{2}$ Division of Leisure \& Sports Science, Department of Exercise Prescription, Dongseo University, Busan, Korea \\ ${ }^{3}$ Department of Biochemistry and Molecular Biology, Kyung Hee University School of Medicine, Seoul, Korea \\ ${ }^{4}$ Department of Urology, Samsung Changwon Hospital, Sungkyunkwan University School of Medicine, Changwon, Korea \\ ${ }^{5}$ Division of Sports Science, Baekseok University. Cheonan, Korea
}

Purpose: Stress is associated with depression, which induces many psychiatric disorders. Serotonin, also known as 5-hydroxytryptamine (5-HT), acts as a biochemical messenger and regulator in the brain. It also mediates several important physiological functions. Depression is closely associated with an overactive bladder. In the present study, we investigated the effect of treadmill exercise on stress-induced depression while focusing on the expression of 5-HT 1A (5- $\left.\mathrm{HT}_{1 \mathrm{~A}}\right)$ receptors in the dorsal raphe.

Methods: Stress was induced by applying a 0.2-mA electric foot shock to rats. Each set of electric foot shocks comprised a 6-second shock duration that was repeated 10 times with a 30-second interval. Three sets of electric foot shocks were applied each day for 7 days. For the confirmation of depressive state, a forced swimming test was performed. To visualize the expression of 5-HT and tryptophan hydroxylase (TPH), immunohistochemistry for 5-HT and TPH in the dorsal raphe was performed. Expression of $5-\mathrm{HT}_{1 \mathrm{~A}}$ receptors was determined by western blot analysis.

Results: A depressive state was induced by stress, and treadmill exercise alleviated the depression symptoms in the stress-induced rats. Expressions of 5-HT, TPH, and HT 1A in the dorsal raphe were reduced by the induction of stress. Treadmill exercise increased 5-HT, TPH, and HT 1A expressions in the stress-induced rats.

Conclusions: Treadmill exercise enhanced 5-HT synthesis through the up-regulation of 5- $\mathrm{HT}_{1 \mathrm{~A}}$ receptors, and improved the stress-induced depression. In the present study, treadmill exercise improved depression symptoms by enhancing $5-\mathrm{HT}_{1 \mathrm{~A}}$ receptor expression. The present results suggest that treadmill exercise might be helpful for the alleviation of overactive bladder and improve sexual function.

Keywords: Stress, Psychological; Depression; Serotonin; Exercise Test

- Grant Support: This study was supported by the National Research Foundation of Korea Grant funded by the Korean Government (NRF2012S1A5A8022111).

- Research Ethics: All animal experimental procedures conformed to the regulations stipulated by the National Institutes of Health (NIH), and the guidelines of the Korean Academy of Medical Science. This study was approved by the Kyung Hee University Institutional Animal Care and Use Committee (Seoul, Korea) (KHUASP[SE]-13-038).

- Conflict of Interest: No potential conflict of interest relevant to this article is reported.

Corresponding author: Jin Hee Seo (iD http://orcid.org/0000-0003-2766-1282 Division of Sports Science, Baekseok University, 76 Munam-ro, Dongnam-gu, Cheonan 330-704, Korea

E-mail: sjh0521@bu.ac.kr / Tel: +82-41-550-2270 / Fax: +82-41-550-2109

Submitted: March 10, 2015 / Accepted after revision: March 16, 2015
This is an Open Access article distributed under the terms of the Creative Commons Attribution Non-Commercial License (http://creativecommons.org/licenses/by-nc/3.0/) which permits unrestricted non-commercial use, distribution, and reproduction in any medium, provided the original work is properly cited. 


\section{INTRODUCTION}

Stress contributes to symptom exacerbation in many disease states [1], and is closely associated with depression [2,3]. Depression is a major mental health problem and a significant public-health issue in the community. It is caused by chronic physical disease, alcohol addiction, and stress [4,5]. It induces many psychiatric disorders, such as sleep disorder, anxiety, appetite disorder, and in severe cases, suicide. The various brain areas altered by stress include the hippocampus and the dorsal raphe; dorsal raphe nuclei are strongly associated with depression [6]. Depression is closely associated with overactive bladder symptoms [7].

Serotonin, also known as 5-hydroxytryptamine (5-HT), is a monoamine neurotransmitter, which acts as a biochemical messenger and regulator in the brain. 5-HT mediates several important physiological functions including neurotransmission, gastrointestinal motility, hemostasis, and cardiovascular integrity. It is generally thought to be a contributor to feelings of well-being and happiness [8]. 5-HT is closely associated with depression [9], and decrement in 5-HT metabolism was ascertained in the brains of a subgroup of patients with depression [10]. Tryptophan hydroxylase (TPH), the rate-limiting enzyme in 5-HT synthesis, regulates 5-HT activity in the brain [11].

5-HT interacts with 14 serotonin receptors (5-HT receptors) that can be subdivided into 7 classes. Of these, the 5-HT 1A (5$\mathrm{HT}_{1 \mathrm{~A}}$ ) receptor is a subtype located in the presynaptic and postsynaptic regions. Presynaptic 5-HT release is regulated by the $5-\mathrm{HT}_{1 \mathrm{~A}}$ autoreceptors in the raphe nuclei of the midbrain. Raphe nuclei are the pacemakers of 5-HT central propagation, which regulates the 5-HT projection in various brain areas [12]. In particular, the dorsal raphe nuclei are closely implicated in mood disorders such as depression [6]. Anxiolytic, antidepressant, and antipsychotic medications act via the activation of $5-\mathrm{HT}_{1 \mathrm{~A}}$ receptors $[13,14]$.

Treatment of stress-induced depression and particularly, its prevention should be geared towards reduction of stress and stress sensitivity [10]. Exercise has been recommended as a valuable strategy for symptom relief in many neuropsychiatric disorders [15-17]. Exercise protects neurons against neuronal injuries and ameliorates the progression of many neuropsychiatric disorders, such as Alzheimer disease, Parkinson disease, and autism $[15,16,18,19]$. Additionally, exercise is known to alleviate symptoms of depression [20,21]. Exercise also improves sexual function in women taking antidepressants [22].
However, little information is available regarding the effect of treadmill exercise on the stress-induced depressive state. In the present study, we investigated the effect of treadmill exercise on depression induced by stress while focusing on the expression of $5-\mathrm{HT}_{1 \mathrm{~A}}$ receptors in the dorsal raphe.

\section{MATERIALS AND METHODS}

\section{Animals}

Sprague-Dawley rats, weighing $100 \pm 10 \mathrm{~g}$ (5 weeks old), were obtained from a commercial breeder (Orient Co., Seoul, Korea) for the experiments. The experimental procedures were performed in accordance with the animal care guidelines of the National Institutes of Health and the Korean Academy of Medical Sciences. The rats were housed under controlled temperature $\left(20^{\circ} \mathrm{C} \pm 2^{\circ} \mathrm{C}\right)$ and lighting (7 AM to $\left.7 \mathrm{PM}\right)$ conditions with food and water available ad libitum. They were randomly divided into 4 groups ( $\mathrm{n}=10$ per group): control, control and exercise, stress-induced, and stress-induced and exercise groups.

\section{Induction of Stress}

Stress was induced by applying an inescapable $0.2-\mathrm{mA}$ electric foot shock to the rats. One set of electric foot shocks comprised a 6-second shock duration that was repeated 10 times with a 30 -second interval. The rats in the stress-induced groups received three sets of electric foot shocks per day. Exposure of the rats to the electric foot shock continued for 7 days.

\section{Exercise Protocol}

The rats in the exercise groups were made to run on a motorized treadmill for 30 minutes once a day for 4 weeks. The exercise load consisted of running at a speed of $5 \mathrm{~m} / \mathrm{min}$ for the first 5 minutes, $8 \mathrm{~m} / \mathrm{min}$ for the next 5 minutes, and $15 \mathrm{~m} / \mathrm{min}$ for the last 20 minutes, with a $0^{\circ}$ inclination. The rats in the control group and the stress-induced group were left on a treadmill that was not running for the same period as the exercise groups.

\section{Forced Swimming Test}

For the confirmation of depressive state, a forced swimming test was performed, according to a previously described method $[4,20]$. Experimental animals were dropped individually into glass cylinders. The glass cylinders (height, $50 \mathrm{~cm}$; diameter, 15 $\mathrm{cm}$ ) contained water at a temperature of $27^{\circ} \mathrm{C}$ and a depth of about $30 \mathrm{~cm}$. All experimental rats underwent a 15 -minute pretest for adaptation to the water. One day after the pretest, the 
animals were tested for 5 minutes. During the test session, immobility time and climbing time were analyzed using a Smart ver. 2.5 video tracking system (Panlab, Barcelona, Spain). Climbing behavior consisted of upward-directed movements of the forepaws along the side of the swim chamber. Immobility was defined to occur when no additional activity was observed other than the actions to keep the animal's head above the water.

\section{Tissue Preparation}

The animals were sacrificed immediately after the forced swimming test. To prepare the brain slices, the animals were fully anesthetized with Zoletil 50 (10 mg/kg, intraperitoneally; Vibac, Carros, France), transcardially perfused with $50 \mathrm{mM}$ phosphatebuffered saline (PBS), and then fixed with a freshly prepared solution of $4 \%$ paraformaldehyde in $100 \mathrm{mM}$ phosphate buffer ( $\mathrm{PB}, \mathrm{pH} 7.4)$. The brains were removed, postfixed in the same fixative overnight, and transferred into a 30\% sucrose solution for cryoprotection. Coronal sections of $40-\mu \mathrm{m}$ thickness were made using a freezing microtome (Leica, Nussloch, Germany).

\section{Immunohistochemistry for 5-HT and TPH Expressions}

To visualize 5-HT and TPH expressions, immunohistochemistry for 5-HT and TPH in the dorsal raphe was performed, according to a previously described method [11]. The dorsal raphe spanning 7.20 to $8.00 \mathrm{~mm}$ from the Bregma was obtained from each brain. The sections were incubated in PBS for 10 minutes, and then washed three times in the same buffer. The sections were then incubated in $1 \% \mathrm{H}_{2} \mathrm{O}_{2}$ for 30 minutes. They were then incubated overnight with rabbit anti-5-HT antibody (1:500, Abcam, Cambridge, UK) or rabbit anti-TPH antibody (1:1,000; Oncogene Research Product, Cambridge, UK). This was followed by incubation with biotinylated rabbit secondary antibodies (1:200; Vector Laboratories Inc., Burlingame, CA, USA) for another 1 hour. The secondary antibodies were amplified with the Vector Elite ABC kit (1:100; Vector Laboratories Inc.). Antibody-biotin-avidin-peroxidase complexes were visualized using $0.03 \%$ diaminobenzidine (DAB), and the sections were mounted onto gelatin-coated slides. The slides were airdried overnight at room temperature, and coverslips were mounted using Permount (Fisher Scientific, Pittsburgh, PA, USA).

\section{Western Blot for $5-\mathrm{HT}_{1 \mathrm{~A}}$ Receptors}

Western blot for the $5-\mathrm{HT}_{1 \mathrm{~A}}$ receptor was performed, according to a previously described method $[16,17]$. The dorsal raphe was collected and immediately frozen at $-70^{\circ} \mathrm{C}$. Protein from each dorsal raphe was extracted. The tissues were homogenized with lysis buffer containing 50mM Tris- $\mathrm{HCl}$ (pH 8.0), $150 \mathrm{mM} \mathrm{NaCl}$, $10 \%$ glycerol, $1 \%$ Triton X-100, $1.5 \mathrm{mM} \mathrm{MgCl} \cdot 6 \mathrm{H}_{2} \mathrm{O}, 1 \mathrm{mM}$ ethyleneglycotetraacetic acid, $1 \mathrm{mM}$ phenylmethylsulfonyl fluoride, $1 \mathrm{mM} \mathrm{Na}_{2} \mathrm{VO}_{4}$, and $100 \mathrm{mM} \mathrm{NaF}$, then ultracentrifuged at $50,000 \mathrm{rpm}$ for 1 hour. Protein content was measured using a Bio-Rad colorimetric protein assay kit (Bio-Rad, Hercules, CA, USA). Protein $(30 \mu \mathrm{g})$ was separated on sodium dodecyl sulfate-polyacrylamide gels and transferred onto nitrocellulose membranes. Anti-GAPDH antibody (1:3,000; Abcam) and anti-5- $\mathrm{HT}_{1 \mathrm{~A}}$ antibody (1:1,000; Abcam) were used as the primary antibodies. Horseradish peroxidase-conjugated antimouse antibodies for GAPDH and 5- $\mathrm{HT}_{1 \mathrm{~A}}$ were used as the secondary antibodies. Experiments were performed in normal laboratory conditions and at room temperature, except for the transferred membranes. Membrane transfer was performed at $4^{\circ} \mathrm{C}$ with a cold pack and prechilled buffer. Band detection was performed using the enhanced chemiluminescence detection kit (Amersham Pharmacia Biotech GmbH, Freiburg, Germany).

\section{Data Analysis}

For confirming the expression of 5- $\mathrm{HT}_{1 \mathrm{~A}}$ receptors, the detected bands were quantified densitometrically using Molecular Analyst ver. 1.4.1 (Bio-Rad). The numbers of 5-HT and TPH-positive cells in the dorsal raphe were counted hemilaterally under a light microscope (Olympus, Tokyo, Japan). The data were analyzed with one-way analysis of variance followed by the Duncan post hoc test. All values are expressed as the mean \pm standard error of the mean. P-value $<0.05$ was considered significant.

\section{RESULTS}

\section{Effect of Treadmill Exercise on Depressive State}

The results of the forced swimming test are presented in Fig. 1. The average time of immobility in the control, control and exercise, stress-induced, and stress-induced and exercise groups were 9.28 $\pm 2.00,4.92 \pm 0.98,78.81 \pm 10.67$, and $43.21 \pm 10.56$ seconds, respectively. The average time of climbing in the groups was $189.52 \pm 13.00,180.29 \pm 8.90,20.00 \pm 4.07$, and $62.08 \pm 10.70$ seconds, respectively. Induction of stress increased the immobility time and decreased the climbing time $(\mathrm{P}<0.05)$. In contrast, treadmill exercise decreased the immobility time and increased the climbing time in the stress-induced rats $(\mathrm{P}<0.05)$. 

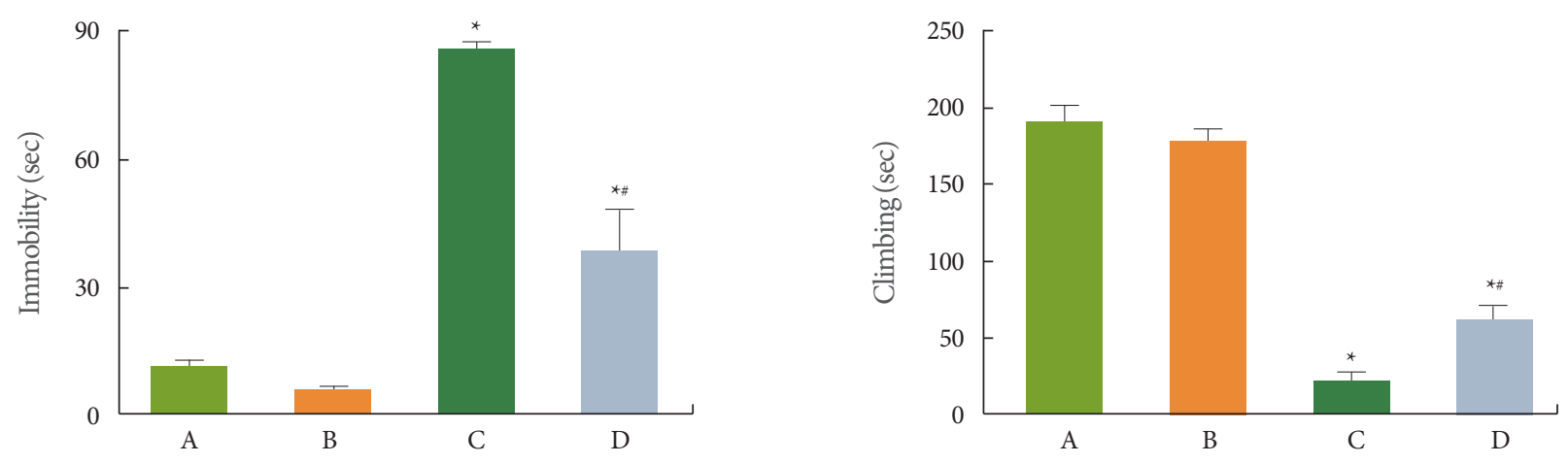

Fig. 1. Effect of treadmill exercise on depression-like behavior in the forced swimming task. (A) Control group, (B) control and exercise group, (C) stress-induced group, and (D) stress-induced and exercise group. The data are presented as the mean \pm standard error of the mean. ${ }^{*} \mathrm{P}<0.05$ compared with the control group. ${ }^{*} \mathrm{P}<0.05$ compared with the stress-induced group.

\section{Effect of Treadmill Exercise on 5-HT Expression in the Dorsal Raphe}

Photomicrographs of 5-HT-positive cells in the dorsal raphe are shown in Fig. 2. The number of 5-HT-positive cells in the control, control and exercise, stress-induced, and stress-induced and exercise group were $299.7 \pm 8.42,277.70 \pm 5.14,170.10 \pm 5.49$, and $210.30 \pm 6.00$, respectively. Induction of stress reduced the expression of 5-HT in the dorsal raphe $(\mathrm{P}<0.05)$. In contrast, treadmill exercise increased 5-HT expression in the stress-induced rats $(\mathrm{P}<0.05)$.

\section{Effect of Treadmill Exercise on TPH Expression in the Dorsal Raphe}

Photomicrographs of TPH-positive cells in the dorsal raphe are shown in Fig. 3. The number of TPH-positive cells in the control, control and exercise, stress-induced, and stress-induced and exercise group were $551.37 \pm 45.35,568.25 \pm 37.94,270.08$ \pm 36.14 , and $381.12 \pm 19.10$, respectively. Induction of stress reduced the expression of TPH in the dorsal raphe $(\mathrm{P}<0.05)$. In contrast, treadmill exercise increased TPH expression in the stress-induced rats $(\mathrm{P}<0.05)$.

\section{Effect of Treadmill Exercise on 5- $\mathrm{HT}_{1 \mathrm{~A}}$ Receptor Expression in the Dorsal Raphe}

$5-\mathrm{HT}_{1 \mathrm{~A}}$ receptor expression is shown in Fig. 4. When the level of $5-\mathrm{HT}_{1 \mathrm{~A}}$ in the control group was set at 1.00 , the levels of $5-\mathrm{HT}_{1 \mathrm{~A}}$ in the control and exercise, stress-induced, and stressinduced and exercise group were $0.92 \pm 0.02,0.67 \pm 0.05$, and $0.87 \pm 0.06$, respectively. Induction of stress reduced the expression of $5-\mathrm{HT}_{1 \mathrm{~A}}$ in the dorsal raphe $(\mathrm{P}<0.05)$. In contrast, treadmill exercise enhanced 5- $\mathrm{HT}_{1 \mathrm{~A}}$ expression in the stress-induced rats $(\mathrm{P}<0.05)$.

\section{DISCUSSION}

Exercise is effective for reducing the symptoms of depression and anxiety [21]. A decrease in climbing time and an increase in immobility time in the forced swimming test indicate depressive state in the tested animals [4]. In the present study, the climbing time decreased and the immobility time increased in the stress-induced rats. Stress-induced depression in the forced swimming test was alleviated by treadmill exercise (Fig. 1). These results demonstrate that treadmill exercise exerted an antidepressant-like effect.

The 5-HT in the dorsal and median raphe nuclei ramifies to most of the brain regions, and 5-HT is implicated in emotions, anxiety, and depression [23]. TPH regulates 5-HT activity, and is used as an indicator of serotonin synthesis [24]. Increase in 5-HT synthesis and TPH expression caused by treadmill exercise is well documented [11,20]. Increment of serotonin synthesis and activity might be involved in the antidepressant effect of exercise in the elderly [25]. Baek et al. [20] showed that treadmill exercise increased 5-HT and TPH expressions and ameliorated depression symptoms. In the present study, 5-HT and TPH expressions in the dorsal raphe were suppressed by exposure to stress, and treadmill exercise enhanced 5-HT and TPH expressions in the stress-exposed rats (Figs. 2,3). These results suggest that treadmill exercise ameliorated stress-induced depression through enhancing serotonin synthesis.

Altered transcription of the $5-\mathrm{HT}_{1 \mathrm{~A}}$ receptors affects the serotonin system and leads to a predisposition to depression. The desensitization of $5-\mathrm{HT}_{1 \mathrm{~A}}$ autoreceptors is implicated in the 

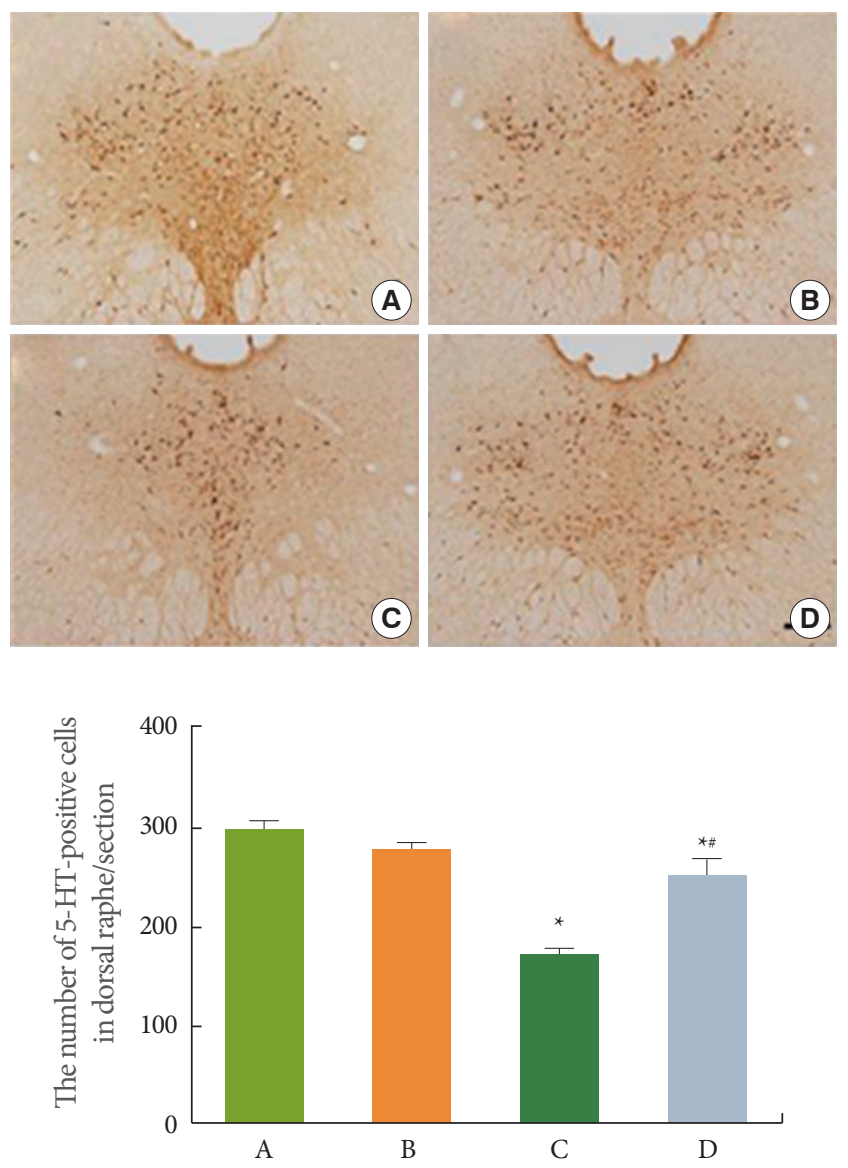

Fig. 2. Effect of treadmill exercise on 5-hydroxytryptamine (5HT) expression in the dorsal raphe. Upper: Photomicrographs of 5-HT-positive cells in 5-HT immunohistochemistry. The scale bar represents $200 \mu \mathrm{m}$. Lower: number of 5-HT-positive cells in each group. (A) Control group, (B) control and exercise group, (C) stress-induced group, and (D) stress-induced and exercise group. The data are presented as the mean \pm standard error of the mean. ${ }^{*} \mathrm{P}<0.05$ compared with the control group. ${ }^{*} \mathrm{P}<0.05$ compared with the stress-induced group.

treatment by antidepressants [13]. Savitz et al. [14] raised the possibility that $5-\mathrm{HT}_{1 \mathrm{~A}}$ receptor dysfunction represents a potential mechanism underpinning major depressive disorder and other stress-related disorders. Greenwood et al. [26] demonstrated that wheel running increased $5-\mathrm{HT}_{1 \mathrm{~A}}$ mRNA levels in the dorsal raphe nuclei. In the present study, expression of $5-\mathrm{HT}_{1 \mathrm{~A}}$ receptors in the dorsal raphe was reduced by exposure to stress, and treadmill exercise increased the expression of $5-\mathrm{HT}_{1 \mathrm{~A}}$ receptors in the stress-exposed rats (Fig. 4). These results suggest that treadmill exercise up-regulated $5-\mathrm{HT}_{1 \mathrm{~A}}$ receptors under stressful conditions.
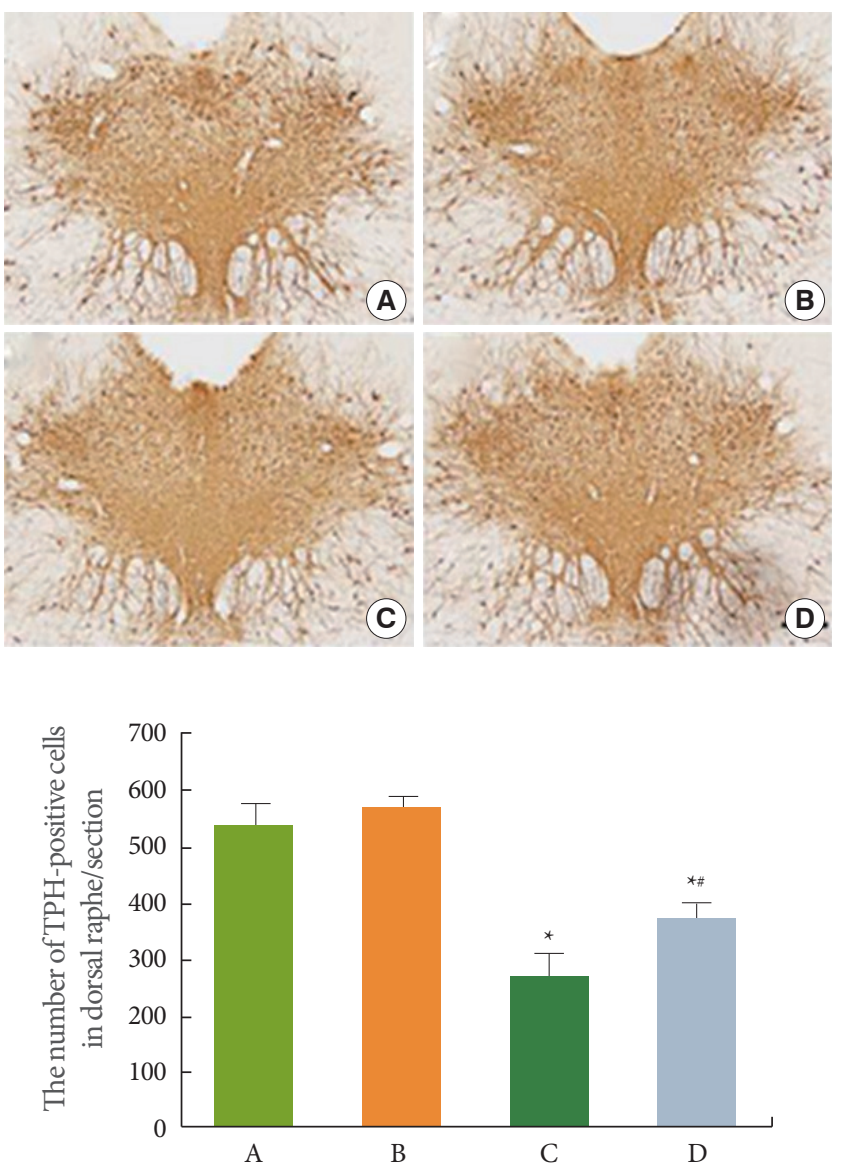

Fig. 3. Effect of treadmill exercise on tryptophan hydroxylase (TPH) expression in the dorsal raphe. Upper: Photomicrographs of TPH-positive cells in TPH immunohistochemistry. The scale bar represents $200 \mu \mathrm{m}$. Lower: number of TPH-positive cells in each group. (A) Control group, (B) control and exercise group, (C) stress-induced group, and (D) stress-induced and exercise group. The data are presented as the mean \pm standard error of the mean. ${ }^{*} \mathrm{P}<0.05$ compared with the control group. ${ }^{*} \mathrm{P}<0.05$ compared with the stress-induced group.

Overactive bladder symptoms are quite bothersome, especially for women, and they increase depression [27]. Ko et al. [28] suggested that physical exercise is a valuable tool for remarkable improvement of overactive bladder symptoms. The present results demonstrate that treadmill exercise enhances 5 -HT synthesis through the up-regulation of $5-\mathrm{HT}_{1 \mathrm{~A}}$ receptors, and improves stress-induced depressive symptoms. Physical inactivity, diabetes, hypertension, dyslipidemia, smoking, and obesity are associated with imbalance in oxidative stress, leading to endothelial dysfunction. Such endothelial dysfunction is present in cases of erectile dysfunction [29]. Activation or up- 

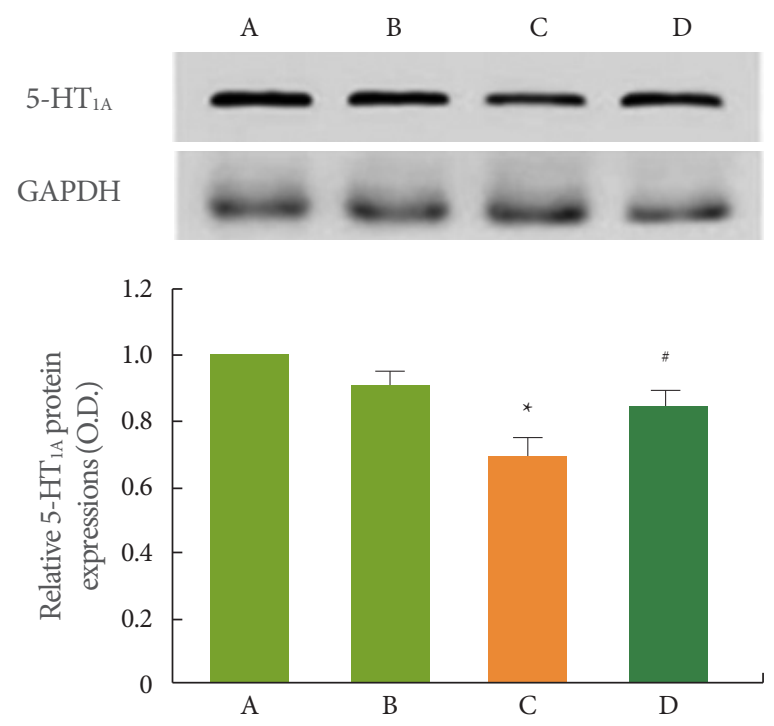

Fig. 4. Effect of treadmill exercise on 5-hydroxytryptamine 1A (5- $\mathrm{HT}_{1 \mathrm{~A}}$ ) receptor expression in the dorsal raphe. (A) Control group, (B) control and exercise group, (C) stress-induced group, and (D) stress-induced and exercise group. The data are presented as the mean \pm standard error of the mean. ${ }^{*} \mathrm{P}<0.05 \mathrm{com}$ pared with the control group. ${ }^{*} \mathrm{P}<0.05$ compared with the stress-induced group.

regulation of receptors is strongly implicated in the therapeutic strategy for many diseases [30,31]. Leoni et al. [29] suggested the role of physical exercise in the modulation of endothelial function and its implications on erectile function.

Depression aggravates symptoms of an overactive bladder [7] and patients taking antidepressants complain of sexual dysfunction [22]. In the present study, treadmill exercise improved depression symptoms through enhancing $5-\mathrm{HT}_{1 \mathrm{~A}}$ receptor expression. The present results suggest that treadmill exercise might be helpful for the alleviation of overactive bladder symptoms and might improve sexual function.

\section{REFERENCES}

1. Grant KE, Compas BE, Thurm AE, McMahon SD, Gipson PY. Stressors and child and adolescent psychopathology: measurement issues and prospective effects. J Clin Child Adolesc Psychol 2004; 33:412-25.

2. Goldstein AL, Walton MA, Cunningham RM, Trowbridge MJ, Maio RF. Violence and substance use as risk factors for depressive symptoms among adolescents in an urban emergency department. J Adolesc Health 2007;40:276-9.
3. Kaltiala-Heino R, Frojd S, Marttunen M. Involvement in bullying and depression in a 2-year follow-up in middle adolescence. Eur Child Adolesc Psychiatry 2010;19:45-55.

4. Kim JE, Ji ES, Seo JH, Lee MH, Cho S, Pak YK, et al. Alcohol exposure induces depression-like behavior by decreasing hippocampal neuronal proliferation through inhibition of the BDNF-ERK pathway in gerbils. Anim Cells Syst 2012;16:190-7.

5. Moussavi S, Chatterji S, Verdes E, Tandon A, Patel V, Ustun B. Depression, chronic diseases, and decrements in health: results from the World Health Surveys. Lancet 2007;370:851-8.

6. Michelsen KA, Prickaerts J, Steinbusch HW. The dorsal raphe nucleus and serotonin: implications for neuroplasticity linked to major depression and Alzheimer's disease. Prog Brain Res 2008;172: 233-64.

7. Kinsey D, Pretorius S, Glover L, Alexander T. The psychological impact of overactive bladder: a systematic review. J Health Psychol 2014 Mar 2 [Epub]. http://dx.doi.org/10.1177/1359105314522084

8. Young SN. How to increase serotonin in the human brain without drugs. J Psychiatry Neurosci 2007;32:394-9.

9. Cowen PJ. Serotonin and depression: pathophysiological mechanism or marketing myth? Trends Pharmacol Sci 2008;29:433-6.

10. van Praag HM. Can stress cause depression? Prog Neuropsychopharmacol Biol Psychiatry 2004;28:891-907.

11. Lee SW, Kim YS, Jun TW, Seo JH, Kim K, Shin MS, et al. The impact of duration of one bout treadmill exercise on cell proliferation and central fatigue in rats. J Exerc Rehabil 2013;9:463-9.

12. Struder HK, Weicker H. Physiology and pathophysiology of the serotonergic system and its implications on mental and physical performance. Part I. Int J Sports Med 2001;22:467-81.

13. Albert PR, Lemonde S. 5-HT1A receptors, gene repression, and depression: guilt by association. Neuroscientist 2004;10:575-93.

14. Savitz J, Lucki I, Drevets WC. 5-HT(1A) receptor function in major depressive disorder. Prog Neurobiol 2009;88:17-31.

15. Kim BK, Shin MS, Kim CJ, Baek SB, Ko YC, Kim YP. Treadmill exercise improves short-term memory by enhancing neurogenesis in amyloid beta-induced Alzheimer disease rats. J Exerc Rehabil 2014;10:2-8.

16. Seo TB, Cho HS, Shin MS, Kim CJ, Ji ES, Baek SS. Treadmill exercise improves behavioral outcomes and spatial learning memory through up-regulation of reelin signaling pathway in autistic rats. J Exerc Rehabil 2013;9:220-9.

17. Seo TB, Kim TW, Shin MS, Ji ES, Cho HS, Lee JM, et al. Aerobic exercise alleviates ischemia-induced memory impairment by enhancing cell proliferation and suppressing neuronal apoptosis in hippocampus. Int Neurourol J 2014;18:187-97. 
18. Cho HS, Shin MS, Song W, Jun TW, Lim BV, Kim YP, et al. Treadmill exercise alleviates short-term memory impairment in 6-hydroxydopamine-induced Parkinson's rats. J Exerc Rehabil 2013;9: 354-61.

19. Sung YH, Kim SC, Hong HP, Park CY, Shin MS, Kim CJ, et al. Treadmill exercise ameliorates dopaminergic neuronal loss through suppressing microglial activation in Parkinson's disease mice. Life Sci 2012;91:1309-16.

20. Baek SS, Jun TW, Kim KJ, Shin MS, Kang SY, Kim CJ. Effects of postnatal treadmill exercise on apoptotic neuronal cell death and cell proliferation of maternal-separated rat pups. Brain Dev 2012; 34:45-56.

21. Wipfli B, Landers D, Nagoshi C, Ringenbach S. An examination of serotonin and psychological variables in the relationship between exercise and mental health. Scand J Med Sci Sports 2011;21:474-81.

22. Lorenz TA, Meston CM. Exercise improves sexual function in women taking antidepressants: results from a randomized crossover trial. Depress Anxiety 2014;31:188-95.

23. Cools R, Roberts AC, Robbins TW. Serotoninergic regulation of emotional and behavioural control processes. Trends Cogn Sci 2008;12:31-40

24. Boldrini M, Underwood MD, Mann JJ, Arango V. More tryptophan hydroxylase in the brainstem dorsal raphe nucleus in depressed suicides. Brain Res 2005;1041:19-28.
25. Melancon MO, Lorrain D, Dionne IJ. Exercise increases tryptophan availability to the brain in older men age 57-70 years. Med Sci Sports Exerc 2012;44:881-7.

26. Greenwood BN, Foley TE, Day HE, Burhans D, Brooks L, Campeau $\mathrm{S}$, et al. Wheel running alters serotonin (5-HT) transporter, 5-HT1A, 5 -HT1B, and alpha $1 \mathrm{~b}$-adrenergic receptor mRNA in the rat raphe nuclei. Biol Psychiatry 2005;57:559-68.

27. Milsom I, Kaplan SA, Coyne KS, Sexton CC, Kopp ZS. Effect of bothersome overactive bladder symptoms on health-related quality of life, anxiety, depression, and treatment seeking in the United States: results from EpiLUTS. Urology 2012;80:90-6.

28. Ko IG, Lim MH, Choi PB, Kim KH, Jee YS. Effect of Long-term Exercise on Voiding Functions in Obese Elderly Women. Int Neurourol J 2013;17:130-8.

29. Leoni LA, Fukushima AR, Rocha LY, Maifrino LB, Rodrigues B. Physical activity on endothelial and erectile dysfunction: a literature review. Aging Male 2014;17:125-30.

30. Han JH, Kim DO, Yi JW, Park SW, Kang WJ, Choi YK, et al. Dexmedetomidine, a2-adrenoceptor agonist, does not induce apoptosis in the brachial plexus of rats. Anim Cells Syst 2014;18:407-15.

31. Jeon JW, Lee JI, Shin HP, Cha JM, Joo KR, Kim SH, et al. Adenosine A2A-receptor agonist polydeoxyribonucleotide promotes gastric ulcer healing in Mongolian gerbils. Anim Cells Syst 2014;18:399406. 